\title{
Prognostic Analysis of The Effects of Starvation and Overfeeding on Children
}

\author{
Le KANG \\ College of pharmacy \\ Henan College of Traditional Chinese Medicine \\ Zhengzhou, Henan, China, 450046 \\ email:394798149@qq.com
}

\author{
Mingsan MIAO* \\ College of pharmacy \\ Henan College of Traditional Chinese Medicine \\ Zhengzhou, Henan, China, 45004 \\ email:miaomingsan@126.com
}

\begin{abstract}
By comparing the effects of excess nutrients and malnutrition on the body of children, It is concluded that the harm to children's body caused by excessive nutrition is more than that of malnutrition, and overnutrition is also a performance of malnutrition. The causes of obesity in children, the present situation of overweight children in our country and the harm to the body of children are reviewed in this paper. The key of treatment of overweight children is to control the child's diet because the importance of correct diet for children's health was analyzed.
\end{abstract}

Keywords-excess nutrients; malnutrition; overweight children; diet

\section{INTRODUCTION}

Overweight and obesity have become popular around the world. According to statistics, there are more than 1 billion 100 million overweight adults in the adult population, of which 312 million were obese, and overweight or obese children more than 155 million. In our country, the detection rate of overweight and obesity was lower in 1985.In 2000, the rate of overweight and obesity has been growing rapidly on a very low base. By 2005, Beijing and other big cities have been fully into the obesity epidemic. Overweight and obesity not only affect the healthy development of children and adolescents, resulting in decreased cardiovascular function, lung function injury, abnormal lipid metabolism, glucose metabolism disorders, but also pose a serious threat to the health of adults, cause a variety of diseases, such as cardiovascular disease, type 2 diabetes, and many types of cancer. Compared to the underweight, which state of overweight and underweight is more harmful to children's body, which is worthy of our in-depth study.

\section{EFFECTS OF OVERWEIGHT AND UNDERWEIGHT ON THE BODY OF YOUNG CHILDREN}

Overweight or obesity refers to a certain degree of overweight and fat layer too thick, and a condition caused by excessive accumulation of body fat, especially triglycerides. It is not simply an increase in body weight, but a state of excess in the body's adipose tissue. Excessive body fat accumulation caused by excessive food intake or changes in body metabolism lead to gain in weight excessively and lead to pathological, physiological changes or latent[1].

Underweight, also known as malnutrition, is the state of any kind of nutritional imbalance, that short-term effects can seriously affect brain development, height and muscle development and important metabolic state during the growth and development of children, and long-term effects can be spread to children's intellectual and cognitive level, immune and ability to work as well as the occurrence of many chronic diseases in adults [2].

Through the above comparison, it is not difficult to see that the harm to children's body caused by excessive nutrition is more than malnutrition. And there are some studies showing that bone age of obese, children were higher than that of thin children. Many parents in order to avoid their children lose at the starting line; rarely let the children go hungry. The result may lead to the child to develop the habit of eating more, and then the risk of obesity in children also rose. 
TABLE I. EFFECTS OF OVERWEIGHT AND UNDERWEIGHT ON THE BODY OF YOUNG CHILDREN

\begin{tabular}{|c|c|c|}
\hline Bodily system & overweight & underweight \\
\hline Endocrine system & $\begin{array}{l}\text { The growth of overweight children is faster than that of normal } \\
\text { children of the same age, height is higher than that of normal } \\
\text { children, with the development of advance, the final height of } \\
\text { most overweight children being at a low value in the normal } \\
\text { range, a few below the normal value. Eventually, he would form } \\
\text { a short and fat body. Sex hormone levels in the body are also } \\
\text { higher than that of the normal children of the same age. At the } \\
\text { same time, obesity is also an important factor in children with } \\
\text { diabetes. High insulin resistance is common in overweight } \\
\text { children, which is easy to cause insulin resistance and cause type } \\
2 \text { diabetes mellitus[3]. }\end{array}$ & $\begin{array}{l}\text { Children's malnutrition can cause physical development of } \\
\text { children, such as shortage in height, bust is insufficient, or } \\
\text { even have some chronic diseases. In the early stage of } \\
\text { malnutrition, there may not be major impact on the height. } \\
\text { While malnutrition early height may not have a big impact, } \\
\text { but it will cause long bone development is slow, which will } \\
\text { cause listlessness, slow response, poor appetite, child diarrhea } \\
\text { and constipation etc. And the early stage of malnutrition, } \\
\text { height may not have much impact, but it could cause bone } \\
\text { development in the long run, which will cause listlessness, } \\
\text { slow response, poor appetite, child diarrhea and constipation } \\
\text { etc. This will cause low blood sugar; the child will appear } \\
\text { pale, breathing difficulties, low body temperature and even } \\
\text { convulsions. }\end{array}$ \\
\hline Reproductive system & $\begin{array}{l}\text { Childhood obesity can also cause sexual developmental } \\
\text { disorders, for example, feminism in boys, virilism in girls, boys } \\
\text { with sexual developmental delay, girls with precocious puberty, } \\
\text { and most of them have menstrual disorders. If they are serious, } \\
\text { they can lead to sexual impotence and reproductive } \\
\text { incompetence. }\end{array}$ & $\begin{array}{l}\text { It could cause growth retardation, as well as reproductive } \\
\text { function decline. And Girls appear less menstrual. }\end{array}$ \\
\hline Cardiovascular system & $\begin{array}{l}\text { Early use of cardiac reserve in the activities of obese children, } \\
\text { cardiac insufficiency, high blood pressure, cholesterol, such as } \\
\text { beta - lipoprotein cholesterol, resulting in high blood lipid. The } \\
\text { blood fat of obese children was significantly higher than that of } \\
\text { normal children, but the blood lipid disorder was the high risk } \\
\text { factor of atherosclerosis. }\end{array}$ & $\begin{array}{l}\text { It would reduce the heart function, blood pressure, blood } \\
\text { lipids. }\end{array}$ \\
\hline Respiratory system & $\begin{array}{l}\text { Severe obesity in children due to excessive thickening of } \\
\text { subcutaneous fat, the development and movement of his chest } \\
\text { and diaphragm will be limited, resulting pulmonary ventilation is } \\
\text { not smooth. The slightest activity would cause the palpitation } \\
\text { and shortness of breath, dyspnea and hypoventilation. Prone to } \\
\text { pneumonia, bronchitis and other lower respiratory infection, } \\
\text { Serious impacted on heart and lung function, and even heart } \\
\text { failure[4]. }\end{array}$ & $\begin{array}{l}\text { Affect the structure and function of respiratory muscles, } \\
\text { reduce the ventilation function and the defense function of the } \\
\text { lung. }\end{array}$ \\
\hline Digestive system & $\begin{array}{l}\text { The prevalence of digestive system disease in obese children was } \\
15 \% \text {, which was significantly higher than that in normal children } \\
\text { (4\%).And prone to fatty liver, the incidence of fatty liver in } \\
\text { severe obesity children up to } 80 \% \text {, and children's obesity is an } \\
\text { important factor to induce fatty liver. }\end{array}$ & Easily lead to indigestion. \\
\hline Immune system & $\begin{array}{l}\text { The immune function of the most obese children is lower than } \\
\text { that of the normal children, and susceptible to infectious } \\
\text { diseases. }\end{array}$ & $\begin{array}{l}\text { Children with poor nutrition, the body's immune system is } \\
\text { relatively low, prone to infection of various diseases, such as } \\
\text { pneumonia, tuberculosis, otitis media, urinary tract infection, } \\
\text { respiratory infections, and even chronic ulcers and other } \\
\text { diseases. }\end{array}$ \\
\hline Other & $\begin{array}{l}\text { Due to excessive weight of the compression of the bone joints, } \\
\text { often with the flat feet, genu varum, lower limb bending, spine } \\
\text { and intervertebral cartilage damage. }\end{array}$ & $\begin{array}{l}\text { Easy to appear O type legs, and could affect the development } \\
\text { of intelligence. Obesity resulting in excessive accumulation of } \\
\text { fat in the brain tissue, the formation of fat brain, to make the } \\
\text { sulcus and gyrus of brain tightly together, fold reduced, the } \\
\text { cerebral cortex becomes smooth, affect the normal } \\
\text { development of intelligence. }\end{array}$ \\
\hline
\end{tabular}

\section{OVERNUTRITION Is Also A PERFORMANCE OF MALNUTRITION}

Malnutrition or nutritional disorders will no longer be limited to people to see the picture of the starving children, in nutrition, nutritional excess is actually another kind of malnutrition symptoms. WHO Nutrition Committee chairman at the 2005 annual meeting said that the current concept of malnutrition needs to be re defined, it is no longer simply refers to the lack of nutrition, but also should include the problem of excess nutrients. In fact, there is no real surplus, but the nutritional imbalance. Usually due to poor diet, poor food quality, lack of exercise, eventually leads to a decline in health conditions and other a series of problems. Therefore, malnutrition means underweight, but also means that overweight.

\section{The CAUSE OF ChILDHOOd OBESITY}

Love children are the common point of all parents, and sometimes even a little spoiled. Regardless of whether the child is hungry, whether there is a need to eat will not stop feeding the child. But it is not good for children's physical 
health and mental development. Some studies have indicated that the health degree and intelligence level of the infants crying because of hunger are often higher than those receiving regular feeding and little feeling of hunger. If you want a healthy child, "you should always keep a little hungry, a little cold", which is a thousand years to prove effective folk parenting Proverbs. In modern society, there are many people violate this principle. There are a lot of obese children, caused by eating too much too full[5].

Many obese children's parents have a mentality: the child to eat fat is a good thing, if you feel bad, to lose weight when they grow up. In fact, people in the process of growth, the growth of fat will go through 3 key periods: 3 months before birth, infancy and 11 years old to 13 years old. If you are too fat in these three periods, then the child is likely to belong to the physique of drink saliva also chairman fat.

The reason, could find from the two classification of obesity. First of all, the number of human fat cells in the above three key periods, the most active hyperplasia, once the excessive hyperplasia of obesity, could cause fat cell increase in obesity. The number of normal human fat cells is about 28 billion to 25 billion, while the number of obese children can reach 90 billion 500 million $\sim 63$ billion 500 million, which is 3 times the number of normal human fat cells. Secondly, not in the proliferative phase of these three fat cells, for example, early childhood, adult obesity, known as the fat cell volume increase in obesity that is, the fat cell volume increases and the number is normal.

The type of obesity of fat cell increasing is the most difficult to treat, even if the child is hard to lose weight after adulthood, it is also very easy to rebound. The type of obesity of fat cell volume increasing is relatively easy to control, and weight loss is also easy to see good results. So, 11 years old to 13 years old is the last one to control the child obesity, if adolescent obesity has not been controlled, then about $80 \%$ of the obese children can be developed for adult obesity[6].

\section{Prevalence of Overweight And OBesity in CHILDREN AND ADOLESCENTS IN CHINA}

Since the beginning of 1980s, the prevalence of overweight and obesity in children and adolescents in all areas of our country showed a rapid upward trend. From 1985 to 1991, the phenomenon of overweight and obesity in children and adolescents in China began to spread in the coastal cities and the mainland cities. In 1991 and 1995, the prevalence of obesity in children and adolescents in big cities increased rapidly, while the prevalence of overweight and obesity in children and adolescents in small and medium-sized cities was obvious, and the growth rate began to catch up with the big cities. From 1995 to 2000, the prevalence of overweight and obesity in children and adolescents in large and medium sized cities in China showed an overall upward trend and the prevalence rate of overweight and obesity children in middle and small urban increased more than that of big cities. At the same time, rich country has also begun to emerge in the prevalence of overweight and obesity in children and adolescents. In 2000
- 2005, the average annual growth rate of overweight and obesity in children and adolescents in our country has declined, but it still continues to be popular. The detection rate of overweight and obesity among children in the northern coastal cities of China has been to the average level of developed countries. Between 2005 and 2010, the growth rate of overweight and obesity of children and adolescents in our country was unchanged from the previous $5 \mathrm{~A}$, but the prevalence of overweight and obesity was still in the whole country[7,8,9].There are some information that we should pay attention to. Every year, more obese children more than $20 \%$ of the standard get weightier than ever before. In Primary and middle school students, we could find $1 / 10$ obese children.

In the past, the disease is called "adult disease", but the metabolic syndrome is not only an adult will have to. Eat too much, lack of exercise increased visceral fat, even a child will get diabetes or high blood pressure. Both children and adults, the regular diet is the focus of prevention of obesity.

Obese children are easy to become obese adults; the secret is still in fat cells. The body's total body fat cells have a total of about 30 billion. The number of children in the period has been fixed, after 20 years of age, basically will not increase. Childhood obesity, hoarding too much neutral fat, fat cells will increase more than the average person, and fat cells that were once split will not be reduced. After the obese adult newborn fat cells compared with the young have fat cells, it is easier to hoard neutral fat.

\section{Proper to Maintain Hunger Is Beneficial to Mental Development and Physical Health.}

Modern scientific research proves that the human body is in the state of starvation, pituitary gland will reduce the secretion of death hormone, and promote the body fat decomposition to translate into glycogen, energy, so that maintain the physiological activities of the brain and other important organs. To maintain a moderate hunger, it could reduce the burden on the gastrointestinal tract, increasing the brain's blood supply and increasing the vitality of human. On the contrary, often eat too much, it will increase the burden on the digestive system, reduce the brain's blood supply, and people will become easy to lack of vigor and vitality. Far more than 2000 years ago, the ancient Chinese medical scientists put forward that he must control diet if a person want to maintain the health. And pointed out the dangers of eating too much, it could make muscle and vessel damage, resulting movement problems, hemorrhoids, colorectal diseases and other diseases.

American medical scientists have discovered a gene called longevity gene in rats through an experiment, which is not expressed in general and there is no biological activity. Only when in starvation condition, can the longevity gene express its activity and prolong the life span of the animal. In fact, not just the United States, according to the research of many countries that one of the essential elements of human longevity is the proper hungry. Hungry is a way of keeping in good health. In the modern medical research shows that cancer cells do not eat for five or three 
days and drink proper water, and then the cancer cells die quickly. Hyperplasia and polyps disappear rapidly. Many diseases are related to overeating.

Studies have indicated that if a mouse reduces its intake by $30 \%$ per day, it will be able to extend the life of $30 \%$. Later, the Australian expert's research further concluded: if humans are often keep a little hungry, their life expectancy will increase by $30 \%$ to $20 \%$. Researchers at Britain's University of Oxford and Institute of social and economic research at the University of Essex by comparison of intelligence tests and early feeding status of 10419 children born during 1990-2000, considering the factors of parents' educational level, family income and maternal health, regardless of the difference between breast milk and bottled milk, the average IQ of those who often cry because of hunger and in time to feed was 5 points higher than those who fed children according to schedule. Therefore, proper hunger is good for children's physical health and mental development [10].

\section{EXPECTATION}

In modern society, obesity is considered to be a major chronic disease that affects human health and quality of life. The prevalence rate of obesity in early childhood showed an increasing trend year by year. In particular, the continued rise in childhood obesity has become a global public health problem in the field of medicine and nutrition. Early childhood obesity not only can lead to adult obesity, but also brought to reduce chronic disease of hypertension, hyperlipidemia, diabetes, cardiovascular, respiratory system and other high incidence of chronic diseases or falling ill age, and significantly reduce the children's learning, life and social adaptation ability. Therefore, the treatment of obese children, the key is to control the diet, to adjust their own health through diet. The author through a lot of literature and related books, choosing the diet is obese children most often take them, and they are of great benefit to the health of obese children [11].

Shrimp with cabbage: 10 grams dried shrimp , 200 grams of cabbage, 10 grams of soy sauce , 3 grams of salt and a little MSG. Shrimp with cabbage has the effect of tonifying kidney and beneficial to the stomach, suitable for obese children often to eat.

Three kinds of peel in salt: 200 grams of watermelon peel , scrape off the wax epicarp; 300 grams of winter melon skin, scrape off the downy epicarp; 400 grams of cucumber, remove the flesh; the right amount of salt and MSG. Watermelon peel and cucumber peel have the effect of clearing heat, removing dampness and smooth. These three kinds are together, could receive the effect of weight loss and removing dampness, particularly beneficial to the patient with difficulty in micturition and edema in the extremities.

Candy hawthorn: 500 grams of raw hawthorn, 250 grams of honey. Candy hawthorn can eliminate the fat, and has the effect of cure deficiency, promoting blood circulation for removing blood stasis, and has a certain therapeutic effect on obesity.

Cucumber mixed with shredded meat: 750 grams of fresh cucumber, 100 grams of pork, 3 grams of angelica, 50 grams of sugar, 30 grams of vinegar, 2 grams of salt, 10 grams of ginger, 50 grams of vegetable oil. It has the functions of nourishing yin for moistening dryness, clearing heat and removing dampness. Obese children eat it not only to lose weight, but also ruddy skin.

Reasonable nutrition is a comprehensive and balanced, to meet the needs of the human body for a variety of nutrients. The basic requirements of reasonable nutrition have the following aspects: First, the types of human intake of nutrients, the number, and the proportion to meet the actual needs of the human body. For example, sugar, fat and protein of which energy intake for a long time more than or less than the needs of the human body, will affect the health of the human body. And the proportion of these three kinds of material intake should be appropriate, only rely on any of the material supply of energy, it will cause adverse effects on the human body. In addition, the proper hunger can make the body's organs to get a rest. Many times, the occurrence of disease is not because the food is not enough, but they eat too much. In many ancient books, overeating, abundant fish and meat are called "festergut food". As the name implies, eat a lot of harm to health, no less than the poison of arsenic. Therefore, moderate hunger not only contributes to good health, but also contributes to longevity. Survey data show that life expectancy of obese older people is shorter than that of lean older people 3 to 5 years old. Older people over 90 years old, $80 \%$ of them have the habit of dieting. These all tell us the importance of eating less on health.

\section{ACKNOWLEDGEMENTS}

The research work was supported by Excellent Science and Technology Innovation Team of Henan University (TCJ2014-391), Natural Science Foundation of Henan Province (132300410019) and Science and Technology Innovation Team of Zhengzhou (131PCXTD612).

\section{REFERENCE}

[1] FU Lian-guo, MA Jun, WANG Hai-jun, DONG Bin, WANG Jing-jing, SHANG Xiao-rui et al,"Effects of overweight and obesity on physical function among children and adoles-cents: a multilevel analysis,” JOURNAL OF PEKING UNIVERSITY( HEALTH SCIENCES), Vol 44, No 3, pp. 359-363, Jun 2012.

[2] Zhang Ting, "The effect of malnutrition on children's healthy development,” CJCHC, Vol. 20, No. 5, pp.388-390, May 2012.

[3] XIAO Yun-Wu, HUANG Xue-Mei, DENG Ying-Xia, LONG Hui, CHENG Fang-qun, LONG Guo-wen et al,“Correlation of obesity with C-reactive protein, leptin and insulin sensitive index in children," Chinese Journal of Contemporary Pediatrics, Vol. 8, No. 1, pp.24-26, Feb 2006.

[4] Kohler MJ, van den Heuvel CJ, "Is there a clear link between over-weight/obesity and sleep disordered breathing in children?" Sleep Med, Vol. 12, No. 5, pp. 347-361, 2008

[5] Xiong Guang-lian, Tian Ben-chun, Qian Ling, Cheng Mao-jin, "Research on behavior factors of children obesity," Chin Matern Child Health Care, Vol. 1, No. 19, pp. 78-91, 2004.

[6] WANG Wen-yuan, FU Ping, WANG Zhi-xu, "Progress in study on epidem iological trend and risk factors of childhood obesity," Chinese Journal of Woman and Child Health Research, Vol. 19, No. 6, pp. 591-594, 2008.

[7] Xue Hongmei, Liu Yan, Duan Ruonan, Zhou Xue, Cheng Guo, "Trends of overweight and obesity among children and adolescents in China and related influencing factors,” Chin J Sch Health, Vol. 35, 
No. 8, pp. 1258-1262, Oct 2014.

[8] MA Jun, WU Shuang-sheng, "Trend Analysis of the Prevalence ofObesity and OverweightAmong Schoo-l age Children and Adolescents in China," Chin J Sch Health, Vo.l 30, No. 3, pp. 195-198, March 2009.

[9] JI Cheng-ye, SUN Jun-ling. "Analyses of the epidemiological status of overweight and obesity in Chinese students and the prevalence changes in recent 15 years," JOURNAL OF PEKING
UNIVERSITY(HEALTH SCIENCES), Vol.36, No.2, pp. 194-197, Apr 2004.

[10] Wang Yue-jin, "To explore the related factors of children's intelligence,” Journal of Nanhua University(Medical Edition), Vol. 35, No. 4, pp. 622-623, Jul 2007.

[11] Han Su-qin, "Food therapy for childhood obesity," Shandong food science and technology, No . 3, pp. 24, 2003. 